Reaching inwards not outwards: marketing via the Internet at the UK 2010 General Election

Darren G. Lilleker \& Nigel A. Jackson

\begin{abstract}
The Internet has been to date used as a space for simple promotion by political parties, websites present an opportunity for the delivery of non-mediated communication directly to the online audience and nothing more. However new patterns in usage during campaigns, particularly that of Barack Obama, aided by the technological innovations that fall under the umbrella of Web 2.0, offer new models of online political communication. Through an analysis of the websites and linked online presences of six parties which stood across the UK at the 2010 General Election we find a dual strategy for Internet campaigning emerging. The persuasive traditions of electioneering remain a feature; however the key emergent function is one of internal marketing to party supporters and activists. Large sections of party websites are being dedicated to harnessing supporters and converting them to being donators, promoters and campaigners both online and offline. This suggests that the Internet is increasingly embedded within election communication and online communication strategies are becoming a feature of most of the parties' marketing communication mix.
\end{abstract}

Keywords: UK politics, elections, Internet, Web 2.0, online campaigning

Darren G. Lilleker is Senior Lecturer in the Media School, Bournemouth University The Media School

Bournemouth University

Fern Barrow

Poole

UK

BH12 5BB

dlilleker@bournemouth.ac.uk

Nigel Jackson is a lecturer at Plymouth Business School, University of Plymouth School of Tourism \& Hospitality

University of Plymouth

Cookworthy Building

Drake Circus

Plymouth

Devon

PL4 8AA

Nigelajackson1@aol.com 


\section{Reaching inwards not outwards: marketing via the Internet at the UK 2010 General Election}

While the Internet has played a role in UK General Elections since 1997, 2010 was the first to be vaunted as the first Internet election (Bernstein 2009, Pullin 2010). The verdict after the contest was that websites, the use of social networking sites such as Facebook or tools like Twitter, played a role, but it not as a game changer (Pack, 2010, Dale 2010, Alani 2010). In fact, the campaign appeared to reflect a move away from postmodern tools back to the campaigning environment of the modern era (Norris 2000), with the first ever live televised leaders' debates being the major innovation. Certainly, after the first debate generally believed to have been 'won' by Nick Clegg of the Liberal Democrats his party’s poll ratings surged (Worcester 2010). Television also created a major event when a microphone attached to the then Prime Minister Gordon Brown picked up that in a private conversation with aides he called a voter he had just met "some bigoted woman". These stories flowed around the online ecosystem, but the traditional media led the agenda leading to conclusions that the Internet had still not emerged as a major channel for electioneering.

The big stories may have been televised; however this does not mean that the Internet did not play a role. Thousands added satirical slogans to spoof Conservative posters, joined party political online groups, commented on election related items on official and unofficial online media sites and importantly interacted with each other within party websites. These public activities, facilitated by Web 2.0 technologies, encouraged enhanced dialogue and interaction between voters and politicians beyond that achieved in 2005 (Jackson 2006). Influenced to an extent by innovations introduced during the 2008 campaign in the US of Barack Obama, whose personnel were prominent in the UK 2009-10 and advised parties, there were strong indications that there would be a step change in usage of the Internet beyond simply selling the parties to online browsers (Gibson \& Ward 1998; Coleman 2001) to building relationships with website visitors. This necessitates providing a more participatory architecture which has risks as well as benefits (Stromer-Galley, 2000). Our analysis suggests that largely UK parties tried to balance benefits against risks by following the Obama example partially, combining a sales and relationship marketing approach. 
This paper explores this firstly through introducing our conceptual framework, after discussing the methodological issues we map the architecture of the websites of the six largest parties which stood nationally in the UK against campaigning functions and the philosophies of Web 2.0 to draw conclusions regarding the extent to which a new online, Web 2.0, campaigning style emerged.

\section{Web 2.0 and the Obama-isation of e-campaigning}

Historically the Internet has played a range of key functions within election campaigning (Gibson et al., 2003). First, a website is a key medium for information provision, a space for parties and candidates to present their brand character, personnel and key political proposals in an unmediated environment. Second, campaigning; in terms of presenting persuasive arguments and cues to inform voting behaviour. Third, and a corollary of campaigning is the use of negativity. Increasingly, campaigning is as likely to take an attacking stance against opponents as presenting a positive image of the host (Schweitzer, 2010). Fourth, resource generation, ranging from attracting new members and gaining donations from supporters through to mobilising supporters (Jackson 2006). Fifth, and linked to mobilisation, is networking: providing spaces for supporters and activists to discuss issues and tactics and for the party to communicate directly to their supporters. Historically this has taken place on password protected intranets (Norris, 2001), but some parties have used public forums to create networks. Finally, but the poor relation in terms of functionality, is promoting participation. Often this is limited to mobilising activists or persuading visitors to vote; however there have been some innovative uses of the Internet to gain greater active participation in the form of downloading and sharing materials, contributing to debates and making direct contact with key personnel (Lilleker and Jackson 2011). These functions position the Internet as a central tool within an integrated marketing communication campaign used to reinforce the advertising and media management. The areas that offer some degree of innovation within an online context are those where mobilisation and participation overlap. Traditionally, one may expect these to focus on the act of voting or simple methods of showing support such as printing off and displaying posters; however demonstrations of public support now include a range of methods for endorsing parties or candidates within online networks. 
These more participatory elements are foregrounded within a Web 2.0 online communication paradigm. Despite clear moderation, the key innovation observed of the Obama campaign site was the open and unfettered public involvement allowed in campaign communication. The public were encouraged to contribute in various ways; they were allowed to comment on the Obama news feed which was presented in a weblog format, via the website. Visitors could also join his personal social network www.mybarackobama.com (MyBO), or his presences on fifteen different social networks where the promotion and endorsement of his candidature was encouraged. MyBO encouraged participation in a range of further activities, including telephone canvassing and street campaigning. The unprecedented level of control over campaign communication Obama allowed site visitors and members, and the facilitation of conversation across his site and other presences indicated a new approach in ecampaigning. These innovations replicate a form of local marketing, where the supporter network members are both active online and offline selling the candidate out to a broader audience. The relationships built with supporters were based upon strong political ties to his campaign and the online network and these supporters, in turn, built further relationships within their own social milieu. Thus he managed to mobilise a large network to act as advocates across a range of media while also running a high profile national campaign that could be reinforced by his supportive network. Despite the benefits, on the whole, other elections have demonstrated political parties are reluctant to follow such a course (on Germany see Schweitzer 2011), with standard concerns of losing control over the message, and receiving demands for policy specific detail as well as the Burkean traditions of politics predominating (Stromer-Galley, 2004: Lilleker et al, 2010).

However, Barack Obama was the first to exhibit some adherence to the big ideas of Web 2.0 (O’Reilly, 2005; Anderson, 2007; Chadwick, 2009). Philosophically these suggest the Internet having a fundamentally different role in society and presenting opportunities for the user; as opposed to those who create sites; Web 2.0 thus offers a range of new opportunities for electioneering and political marketing. While O’Reilly focuses on these from the purely technological perspective, these philosophical ideas link more to the ethos of organisations creating sites as it is their strategic decisions over inclusion of technological enhancements that potentiate experiences compatible with Web 2.0. The six big ideas create a framework for understanding the potential 
for a democratisation of political communication as offered by Web 2.0 tools, applications and platforms as well as how parties can harness Web 2.0 to improve the efficacy and reach of an election campaign. First, it is argued that Web 2.0 provides the capacity for individual production and user generated content, users are able to easily upload comments, pictures and videos with minimum effort and technological ability. While this can detract from key brand messages, there is also an opportunity for reinforcement and amplification as well as greater promotion using the online user as a brand advocate. Second, is the notion of harnessing the power of the crowd. With successful campaigns such as catapulting Rage Against the Machine to the UK music chart number one position, it is clear that campaigns can crowd source via social networks. With myriad campaigns, political, corporate and social, using the Internet to leverage power, users can be heard and have power, while campaigners can seek supportive crowds to promote campaigns theoretically creating a win-win situation for both organisations and active publics. Third, arguably, in Web 2.0 environments, the community are a key source of information. Overall these first three big ideas link to one of the key concepts of Web 2.0; rather than the 'we will build it and they will come' philosophy of Web 1.0, Web 2.0 enthusiasts argue that 'they will come and build it' (Birdsall 2007). From a marketing perspective, this again represents myriad ways for amplification and re-promotion of brand messages. Sites such as Facebook or Twitter provide an architecture of participation, the fourth big idea, a space for individuals to create content; without users they would be barren landscapes and their success is reliant on usage. These architectures can be used as online shop fronts for political brands, providing a public demonstration of support and activism around the brand. Participation is at the heart of the fifth big idea, the network effect, whereby the online community members act as conduits of information sharing links, ideas and, importantly, campaign communication. The final big idea of Web 2.0, one which may appear anathema to political campaigners, is openness (Lilleker et al 2010). The increased transparency and accessibility implicit through these ideas is a challenge which many see as outweighing the benefits making many apply the brakes when innovating online. This again has significant implications for offering brand perceptions and impressions to visitors to online presences.

Cumulatively the above potentially offers a new paradigm for online campaigning, and Obama's political journey from outsider to president suggests there is political 
capital in such innovations; though the online strategy alone did not win Obama the election. Indeed, one of the key benefits for Obama was that the Internet helped him raise money which was primarily spent on television adverts. However, Obama's online presence represented ways where he built closer relationships with supporters, as well as a potential marketing tool. Whilst the network created is unlikely to determine policy, it can generate greater loyalty, be presented as a selling point in the same way as sales figures versus rivals can be utilised, while also each supporter can act as a salesperson for the party. Obama's online strategy of inclusiveness mirrored his offline strategy of inclusiveness. We argue that Obama offered a new model for campaigning that may be adopted and adapted for a range of contexts outwith of the trend for borrowing techniques from the US, and not suggesting this as part of a trend of Americanisation, is interesting both from a campaigning and a marketing perspective.

\section{Methodology}

The parties selected for analysis are the main parliamentary parties: Conservative, Labour and Liberal Democrat; and three non-parliamentary national challengers, Green, UK Independence (UKIP) and British National (BNP). The sites were downloaded for strategic content analysis during the first week of May 2010, the week of the UK General Election. Analysis was conducted using a list of 69 discrete items (tools, applications or functions) adapted from Gibson \& Ward’s (2000), methodology. This creates a framework whereby our content analysis assesses the campaigning functions of features: information provision; campaigning; negative campaigning; networking; and promoting participation. In addition, we add resource generation which addresses fundraising and securing volunteers (Anstead and Chadwick 2008). Secondly, through a rich analysis of the website features, their function and the extent to which users are allowed control over reading items and contributing, we assess the extent to which there is an adherence to the big ideas of Web 2.0: space for user generated content, harnessing the power of the crowd, access to data, an architecture for participation, the network effect and openness. The overall numeric counts are presented elsewhere firstly, within a qualitative description of the websites we then link the features to the functionality of the website and the site creator's (the party) intended usage of features by website visitors in order to discuss the role of the Internet within the 2010 UK election. 
Website functions at the 2010 UK General Election

Table 1: Features counts for six major UK parties, organised by function

\section{Categories}

Informational Items

Documents

Policies summed

Issues examined

Number of issues discussed

Statement of

Values/ideology

Newsletters

Number of Newsletters

archived

Media releases

Number of releases

Candidate profile

Election information

Event calendar

Frequently asked questions

Number of FAQs

Negative campaigning

Overall percent of negativity

Videos

Number of Videos

Targeted pages

Number of groups targeted

Targeted download form

Targeted online inquiry form

Targeted online transaction

\section{Mobilisation tools}

Volunteering possible

Donations possible

Merchandise for sale

Cookies

\section{Networking links}

Number of Partisan links

Number of Reference links

Number of Internal links

\section{Engaging features}

Downloads (Number)

Site search

Enmeshing

Navigation Aids

Online games/gimmicks

E-mail contact

E-mail feedback

Online feed back form

Join e-mail list

Questionnaires

\section{Lab Cons LDems Green UKIP BNP}

$\begin{array}{cccccc}1 & 7 & 114 & 5 & 23 & 2 \\ 7 & 5 & 6 & 6 & 20 & 11 \\ \text { yes } & \text { yes } & \text { yes } & \text { yes } & \text { yes } & \text { yes } \\ 14 & 28 & 10 & 16 & 38 & 16 \\ \text { yes } & \text { yes } & \text { yes } & \text { yes } & \text { yes } & \text { yes } \\ & & & & & \\ \text { yes } & \text { yes } & \text { yes } & \text { yes } & \text { yes } & \text { yes } \\ 0 & 0 & 9 & 0 & 0 & 13 \\ & & & & & \\ \text { yes } & \text { yes } & \text { yes } & \text { yes } & \text { yes } & \text { no } \\ 480 & 11330 & 2665 & 2636 & 711 & 0 \\ \text { yes } & \text { yes } & \text { yes } & \text { yes } & \text { yes } & \text { yes } \\ \text { yes } & \text { yes } & \text { yes } & \text { yes } & \text { no } & \text { no } \\ \text { yes } & \text { no } & \text { no } & \text { no } & \text { no } & \text { no } \\ \text { no } & \text { no } & \text { no } & \text { no } & \text { no } & \text { no } \\ 0 & 0 & 0 & 0 & 0 & 0 \\ \text { yes } & \text { yes } & \text { yes } & \text { yes } & \text { yes } & \text { yes } \\ 5 & 20 & 15 & 30 & 45 & 50 \\ \text { yes } & \text { yes } & \text { yes } & \text { yes } & \text { yes } & \text { yes } \\ 16 & 676 & 126 & 129 & 77 & 286 \\ 4 & 3 & 5 & 2 & 0 & 13 \\ 2 & 3 & 5 & 2 & 0 & 4 \\ \text { no } & \text { no } & \text { no } & \text { no } & \text { no } & \text { no } \\ \text { no } & \text { no } & \text { no } & \text { no } & \text { no } & \text { no } \\ \text { no } & \text { no } & \text { no } & \text { no } & \text { no } & \text { no } \\ & & & & & \end{array}$

yes yes

yes yes

yes yes

yes yes

\section{yes}

yes

no

no

yes

yes

$\begin{array}{cc}\text { no } & \text { yes } \\ \text { yes } & \text { yes } \\ \text { yes } & \text { no } \\ \text { no } & \text { no }\end{array}$

no no 
Visitor initiated

questionnaires

Polls

Visitor initiated polls

Petitions

Visitor initiated petitions

Join online campaign

Subscribe to e-newsletter

Membership form to

download

Online membership inquiry

form

Online Membership

transaction

Bulletin board

Blog tools

Ability to share vids/pics

(embed code)

Podcasts

Social networking links

Twitter

RSS

\section{Interactive features}

Ability to upload

content/comments

No of opps to upload

content/comments

Ability of visitors to share

information

Number of opportunities to

share information

Ability of visitors to update

information

Number of opportunities to

update information

Public conversations allowed

via comments or wall

posting

Number of opportunities for

Public conversations

Forum

Chat room

Online debate

Number of opportunities to

debate with leaders

$\begin{array}{cccccc}\text { no } & \text { no } & \text { no } & \text { no } & \text { no } & \text { no } \\ \text { no } & \text { no } & \text { no } & \text { no } & \text { no } & \text { yes } \\ \text { no } & \text { no } & \text { no } & \text { no } & \text { no } & \text { yes } \\ \text { yes } & \text { no } & \text { no } & \text { no } & \text { no } & \text { no } \\ \text { no } & \text { no } & \text { no } & \text { no } & \text { no } & \text { no } \\ \text { yes } & \text { yes } & \text { yes } & \text { yes } & \text { yes } & \text { yes } \\ \text { yes } & \text { yes } & \text { yes } & \text { yes } & \text { yes } & \text { yes } \\ \text { yes } & \text { yes } & \text { yes } & \text { no } & \text { no } & \text { yes } \\ & & & & & \\ \text { yes } & \text { yes } & \text { yes } & \text { yes } & \text { yes } & \text { no } \\ & & & & & \\ \text { yes } & \text { yes } & \text { yes } & \text { yes } & \text { yes } & \text { no } \\ & & & & & \\ \text { no } & \text { no } & \text { yes } & \text { no } & \text { no } & \text { no } \\ \text { no } & \text { yes } & \text { no } & \text { no } & \text { no } & \text { yes } \\ 5 & 50 & 126 & 129 & 0 & 295 \\ & & & & & \\ \text { yes } & \text { yes } & \text { yes } & \text { no } & \text { no } & \text { no } \\ \text { yes } & \text { yes } & \text { yes } & \text { yes } & \text { no } & \text { yes } \\ \text { yes } & \text { yes } & \text { yes } & \text { yes } & \text { no } & \text { no } \\ \text { yes } & \text { yes } & \text { yes } & \text { yes } & \text { yes } & \text { yes }\end{array}$

$\begin{array}{cccccc}\text { yes } & \text { yes } & \text { yes } & \text { yes } & \text { no } & \text { yes } \\ 7 & 1372 & 2658 & 132 & 0 & 5342 \\ \text { yes } & \text { yes } & \text { yes } & \text { yes } & \text { no } & \text { yes } \\ & & & & & \\ 8 & 2785 & 308 & 158 & 0 & 18345 \\ & & & & & \\ \text { yes } & \text { yes } & \text { yes } & \text { yes } & \text { no } & \text { yes } \\ & & & & & \\ 1 & 347 & 308 & 2 & 0 & 4480 \\ & & & & & \\ \text { yes } & \text { yes } & \text { yes } & \text { yes } & \text { no } & \text { yes } \\ & & & & & \\ 551 & 1372 & 2664 & 132 & 0 & 5342 \\ & & & & & \\ \text { yes } & \text { yes } & \text { yes } & \text { no } & \text { no } & \text { yes } \\ \text { yes } & \text { no } & \text { yes } & \text { no } & \text { no } & \text { yes } \\ \text { yes } & \text { yes } & \text { yes } & \text { yes } & \text { no } & \text { yes } \\ 1 & 1026 & 2664 & 1 & 0 & 5342\end{array}$

Table 1 provides a numeric overview of the websites in terms of features present, where appropriate a count, and their functionality. This gives an overall sense of how features combined within sites, and of some patterns across sites. Using this data, as well as observations drawn from strategic qualitative analysis of the way that features are used, we explore firstly the link to campaigning functions and secondly analyse adherence to the big ideas of Web 2.0. 


\section{Information Provision}

Information provision was the key function for all party websites, with the election manifestoes foregrounded by all the parties. These could be read online in totality, or in issue-specific sections, and were available for downloading. The Conservatives even offered the manifesto in a range of electronic formats including policies in bitesize podcasts for downloading to iPods and mp3 players. News was also prominent, Labour's provision of 480 unique items across 48 pages may seem high, but pales into insignificance when compared to the archives of the Liberal Democrats with 2665 items and the Greens with 2538. In fact, information dominated the Green Party and UKIP sites due to their overall size, constituting around $80 \%$ and $100 \%$ respectively of publicly viewable material. The BNP offered a more divergent approach. While the party similarly offered vast amounts of information, this was presented in a weblog format meaning that while informing all information could also be added to by visitors who joined the site. Comments did appear on every item, with some gaining over 2,000 and so the BNP site had an appearance reminiscent of that of Barack Obama. Prioritised by all parties, however, was the presentation of information to site visitors in accessible takeaway formats.

\section{Campaigning}

Campaigning messages equally predominated, by election day the three major parties had a splash screen promoting voting with Labour also encouraging supporters to log into Facebook or Twitter via their site to post to friends and followers the message 'I’m voting Labour'. Overall, however, different elements of campaigning were emphasised apart from the standard function of reinforcing the key message and themes of the campaign. The Internet was clearly recognised as providing media that enabled the mobilisation of supporters. Labour placed the greatest emphasis on encouraging the promotion of the party in various ways as well as providing content to reinforce their message of delivery using the 'Change we see' and 'Why I joined Labour' mini-sites. These were designed to encourage supporters to upload positive comments and evidence of achievements by the Labour government and to provide arguments for voting Labour that may not be carried by a largely hostile mainstream media. The party also encouraged volunteering, donating and joining on each page as well as offering links to party campaigns that visitors could sign up to. The Conservative site had a donate function on each page and led with persuading voters 
to elect the party and avoid the hung parliament; this included numerous fear appeals about the election outcome. Liberal Democrat, Green and UKIP sites focused on persuading in a very traditional campaigning style, as well as the usual invitations to join, donate and volunteer. This persuasive campaigning style was also emphasised across the BNP site, however their campaigning was complemented by the material contributed by the broad group of active campaigners at work within the site. While this promoted their right-wing, nationalistic and homophobic credo, it also created a sense of energy and community for those who desired a space to vent their anger, opinions and ideas.

\section{Negative Campaigning}

Negativity was a clear feature of campaigning, though divergences in strategy can be linked to the positions and stance of the parties. As incumbent government, Labour was almost wholly promotional, though they promoted mini-sites detailing 'The Conservative Risk' and 'The Liberal Democrat Risk'. The Conservative site offered a more mixed message, the campaign area was largely devoted to promoting Conservative policy but also stopping, for example, 'Gordon Brown’s Death Tax', opposing Labour's proposed inheritance tax reforms. Videos also offered a negative tone. The BNP launched personal attacks on party leaders, members and the system. One whole area entitled 'Liars, Buggers and Thieves' exposed the often dubious 'criminal' activities of various elected representatives of the three major parties. The site also included a highly negative tone against the broad notions of a multicultural society and tolerance of homosexuality, both of which included user generated materials which presented evidence, often highly spurious, to support the party's stance on both issues. The other three parties had a less specific negative tone where they positioned themselves as 'US' and created an 'OTHER' against whom attacks were levelled. The Liberal Democrats offered 'a new politics' and real change compared to the old politics of the old parties. Greens talked of being a 'real alternative' as compared to the pseudo-environmentalism of their opponents. UKIP positioned themselves against the EU generally and the parties that had surrendered UK sovereignty while also making personal attacks on Gordon Brown as prime minister and House of Commons Speaker John Bercow, the latter because former UKIP leader Nigel Farage had launched a high profile but unsuccessful campaign to unseat Bercow in Buckingham. Overall, campaigning presented a range of simple 
messages promoting the party; negativity was more propagandistic and replicated the general norms of negative political advertising (Lilleker \& Scullion, 2009).

\section{Resource Generation}

All the parties encouraged visitors to perform some form of activity on behalf of the party. Labour, the Greens, the BNP and the Liberal Democrats all encouraged sharing of videos and pages, invited donations from supporters and sought volunteers for the campaign and the promotion of the party via social networks; UKIP had no outward links to social networks so encouraged no sharing, they also did not explicitly seek volunteers, they did however invite donations via their site. The Conservative site offered a range of opportunities to donate, volunteer and created the MyConservatives.com (MyCons) network which was geared solely to volunteering and donations. Labour's Membersnet also tried to mobilise supporters, a key tool for this was the party I-phone application which allowed users to discover where campaigners were working locally and how to join in. Labour, Conservatives, Liberal Democrats and Greens also heavily promoted themselves on social networks as a way of drawing more online users to their sites. While these features all created a sense of community around the party, the key function appeared to be marketing using the networking features of the Internet. A further important function was that communities enabled parties to harvest the email addresses of supporters who had given the party permission to contact them; this supported message reinforcement and mobilisation activities. This level of activity, however, represents only a modest increase from 2005 (Jackson 2006).

\section{Networking}

Creating a party specific social network was one of the key innovations spearheaded by Obama, and this was picked up by a number of the UK parties. The Conservatives, Liberal Democrats and BNP, in particular, appeared to recognise the importance of building their own bespoke community of supporters. This enabled them to have a loyal audience to communicate with and use to extend their voice online and offline. Labour's Membernet offered a similar function, but the party use of this resource was more limited than their competitors. The BNP were perhaps most effective in creating a community within their own site, though membership was probably no more than 15,000 . The party strategy seemed to provide a space for their radical views to be 
discussed, and to gain them a loyal support base across the UK. Essentially, their site had the appearance of a private forum, or online rally, but one that could be viewed by any visitor. Given the hostility to their ideas within the media and across social networks, their space gave permission for members to be anonymous and so open about their views; all of which were consistent with the party stances on immigration and social justice. Hence it was essentially a tool for gaining members from those already sympathetic to their ideas, and then hardening their views and encouraging them to be activists. These communities offered impressions of the brand but, again, mainly enabled the party to create a network effect among supporters via social networking sites.

Externally, Facebook emerged as the key networking tool. Labour created campaign specific groups as well as having their own fan page (31,468 members); the Conservatives fan page gained 70,732 fans; the Liberal Democrat fan page had just short of 20,000 at the start of the campaign but gained 200\% more members and reached 70,012 following the first TV debate. Despite being pioneers of using Facebook for campaigning rather than just accumulating fans, and promoting it heavily across every page of their website, the Green Party only gained 7,858 fans. UKIP were the losers on Facebook (21 fans), but their page was not promoted and, unlike the other parties, their posters were only for downloading not sharing across the Internet. The BNP did not promote their page as much, but still gained 19,394 fans, this was despite the fact that Facebook user groups against the BNP mobilised more than 800,000 people across over 20 groups.

\section{Promoting Participation}

Apart from UKIP all other parties encouraged some form of participation, beyond voting, from visitors to the site. For the BNP site this ranged from promoting site pages and videos on BNPtv via sharing facilities, commenting on news stories, joining campaign groups or taking on a more politically active role. Largely, the BNP appear to focus mostly on online modes of activism; to work the doorsteps required training, though visitors could sign up to a course. Volunteering and donating was emphasised by the Liberal Democrats and the Green Party, however the former also had their LibDem Act network, a campaigning hub which promoted Liberal Democrat policy initiatives and encouraged local activism on behalf of the party. The 
Conservatives offered two forms of participation within their website. The Blue Blog, launched 26 September 2008, allowed any visitor to discuss topics covering policy, campaigns as well as broader social and political issues. The weblog contained a total of 1026 posts, each gaining on average 32 comments. Secondly, and focused more on gaining activists, MyCons was a direct copy of Obama’s MyBO. MyCons was built around six campaign themes, ten national campaigns and also hosted 330 local campaigns geared towards their candidates in the more marginal constituencies. Each campaign area had a Facebook style wall where members could post comments. However, compared to the BNP website and LibDems Act, activity on MyCons was very low with the largest campaign group only gaining around fifty members and no more than 20 wall contributions. Candidate supporting sites were barely active with none reaching donation targets despite only being set at a maximum of $£ 2,500$; many only received $£ 10$. Thus the BNP, Conservatives and Liberal Democrats both created their own communities within their sites, though there were differences in usage; in contrast it was social networks that Labour concentrated on.

The Labour Doorstep campaign, which had a Twitter hashtag (\#labourdoorstep) and fed directly to the main site, campaign mini-sites and the party's Facebook pages were Labour's key modes for encouraging participation. These spoke largely to those who wished to publicly volunteer and contribute positively to the campaign either on the doorsteps or by uploading supportive content. The Membersnet, which anyone could join, did allow members to create a blog (548 were created) and comment on others and functioned as a members community with light touch control. The format was based on the party intranet, and focused mainly on the network of Constituency Labour Parties.

\section{Web 2.0, the emergence of an interactive strategy and the 2010 UK General Election}

The features which underpin the big ideas of Web 2.0 appear sporadically but consistently across party websites; thus they meet the big ideas of Web 2.0 to an extent. The UKIP site offered no Web 2.0 features whatsoever; the Green Party site very few. Within this section, therefore, we focus only on key innovations on party websites (for a more complete discussion see Lilleker \& Jackson, 2011). 


\section{The capacity for individual production and user generated content}

A key innovation offered within the Labour, Conservative and Liberal Democrat sites were the site members' areas which allowed members to create their own profiles (in the case of the latter two), create spaces for commentary and material, such as the Labour Membersnet blogs, upload material, offer comments and participate broadly in campaign events. While the various items posted may offer a lot of highly similar content, each was an opportunity to participate if only by liking or disliking; some sites offered thousands of opportunities to comment, and on many of the videos, weblog posts or photographs conversations between visitors could be found. These member areas built upon the previous use of Facebook, where the party linked into a large community and attempted to create a personalised space for themselves and their supporters (Jackson \& Lilleker, 2009). Social networking was still used to reinforce the bespoke networks, particularly Facebook and YouTube due to the access they offer to wide audiences. On the whole parties were seldom participants on their fan pages; only Green Party leader Caroline Lucas engaged with visitors.

The BNP site emerged as a replica of that of Obama. 4,680 news items in blog format each receiving comments with the average across them all being 68, with a maximum of 200. The 286 videos within the BNPtv area were similar; in fact every page allowed an element of online co-creation; mostly in the form of comments or uploads, the rest through sharing facilities. In all respects, the branding messages were those of an active community, and helped market the parties as being in-touch with their grassroots.

\section{Harnessing the power of the crowd}

At the heart of many co-creation features was converting supporters into activists. With Twitter tsar Kerry McCarthy as the guiding force, Labour used the hashtag \#labourdoorstep to allow campaigners to relay positive experiences across the network. The feed also appeared directly on the homepage. Site visitors were also encouraged to sign up as fans on Facebook, aided by using pictures of their friends where the information could be gleaned from their ISP. In the final days of the campaign Labour also promoted the 'Word of Mouth' application, supporters would then regularly update Twitter and Facebook with an 'I'm voting Labour message. 
These underpinned the ongoing initiatives 'Why I am Labour' and 'Change we see', which both solicited supportive comments that also fed the main website. The latter innovations were matched by the Conservative Wall, featuring many ordinary individuals stating why they supported Labour. Campaign groups were also used by the Conservatives, for social campaigns and supporting candidates in marginal seats; the Liberal Democrats to support key policies; and the BNP to promote their political stances. The one initiative the Green Party developed was a personalised video where visitors could insert friends' names and up to two political concerns and email it or post it on their Facebook profile. Cumulatively, all parties except UKIP attempted to get the network working for them, promoting their message and extending their reach using the network as a political marketing tool.

\section{Access to data on an epic scale}

Information was certainly offered on an epic scale, though for all parties except for the Liberal Democrats information was tightly branded and related only to the 2010 contest. Data on previous contests and the parties was available elsewhere, and the parties clearly saw their site as a branding tool. It was there to provide site visitors with the information the party wanted them to have, packaged to be persuasive. The areas that contained user generated content could at times detract from the key messages but these tended to be distant from the hub of the site; within member areas on a wall or a comment on a weblog post.

\section{An architecture of participation}

The party social networks, MyCons, Labour Membersnet and LibDem Act, were each a participatory architecture. Although bracketed from the main body of the website, they were integral parts that were promoted heavily and joining was encouraged. This was also true of the Conservatives’ Blue Blog. The Conservatives also used Cover it Live, a web-based chat programme, that permitted any number of individuals to submit comments during all three televised leaders debates so creating, for those events, a hub of conversation for supporters. The BNP site was, however, a single architecture of participation which was constantly fed by a tight community of right wing activists. The site appeared to be a haven for marginalised voices promoted and built upon the party campaigns against multiculturalism, and the acceptance of homosexuality. There were no dissenting voices on the site; it acted as a private 
public sphere for extremist political views. Interestingly, however, each of the partybuilt architectures of participation offered the same series of impressions for visitors; hence the impression of them as branding and perception management tools.

\section{The network effect}

Apart from UKIP all parties had built sites which attempted to use the network as a marketing tool. The Greens used only Facebook, whereas the other parties used their own network as a hub for drawing supporters closer to the party. However, it was not only online networks that earned the party supporters within the Facebook public network. David Cameron's Conservatives took four years to gather over 70,000 fans; it took Nick Clegg's appearance on the first televised leader debate to match them. But perhaps the Internet can also be a catalyst for a network effect, during election week the fifth most viewed viral party produced video was a Conservative attack on Gordon Brown; this was shared from their website via Facebook and Twitter. However, the most viewed election-related video was a remake of the pop song Common People by Pulp which poked fun at the privileged background of senior Conservatives. The network effect had its own dynamics, attempts to harness it were marginally successful and shortlived.

\section{Openness}

The networks created by the parties can be perceived as an indication of a degree inclusivity and connectedness, however Web 2.0 was mainly utilised to gain donations, volunteers and get the message out. There was little transparency, only the Liberal Democrats had any documents on their website beyond the manifesto or promotional materials. Openness was thus a chimera, a marketing tool in the same way as the Conservative manifesto title 'Invitation to join the Government of Britain' was more rhetorical than real. The community of supporters did not have open debates, these took place elsewhere online, and even party-linked debate sites went quiet for the duration of the contest.

The BNP built on previous innovations to build a site that was wholly participatory. The Conservatives and Liberal Democrats maintained their external social networking while building spaces for their own communities to interact with one another, as well as with the broader online community. The Conservatives also embraced blogging 
and used it to test ideas outside of campaigns, as well as to gain some element of feedback on thinking at the micro if not macro level. In contrast Labour, the Green Party and UKIP created sites that were lean campaigning tools designed for information provision, with other elements kept to a minimum. Labour concentrated on the defence of their time in government, the Greens and UKIP as presenting themselves as an alternative to soft environmentalists or pro-integrationists.

\section{Conclusion}

The parties use of the Internet was clearly greater than that identified in 2005 (Stanyer 2005; Jackson 2006), but it did not dominate the campaign in the way anticipated. As a consequence the 2010 campaign represented an additional step towards post-modern campaigning (Norris 2000), but not a critically important step. The slightly enhanced role that the Internet played for parties was more sophisticated than before, but its real strength was behind the scenes. Our data does support the suggestion made by Gibson and Ward (2000) that a party website is essentially an information providing tool. As a marketing tool it is, therefore, essentially an electronic brochure that provides voters who visit general information about the party. But the Web's marketing role was much more refined in 2010 than 2005; the key development being that parties increasingly used their Internet presence as a major tool for internal marketing. Whilst the home page of a website did allow a party to speak to floating voters, but the key intended audience were party supporters, members and activists who were encouraged to donate money and offer their time. This trend towards internal marketing was present in 2005, but it is much more marked in 2010. The rise of the Internet as an internal marketing tool is probably the single largest development of the parties’ online campaigns in 2010.

Hence, party use of the Internet adheres to two main functions, the homepage acts as a shopfront which sells the party and its personnel to website visitors, the key target being floating or uncertain voters. However, the interactive nodes are designed to convert latent and loyal supporters into activists: donating, publicly endorsing the party or campaigning offline. In terms of functionality there is an equalisation across the parties, though sophistication of design remains imbalanced towards the major players. Websites and social media have become key tools of campaigns, but have not fundamentally changed the nature of campaigning. This is not to say that Web 2.0 has 
no impact on electioneering. The network effect is difficult to manufacture and relies on the activities of members of the online community; as was evident with the low engagement within MyCons. While many members of the public may have engaged in political talk at election times, in bars and cafes for example, this talk can now be carried out in public places that are globally accessible. However the nature of the talk that filtered through to political party websites was solidly on message and enhanced the campaign, thus within these spaces the public voice became an extension of the party brand. Thus we find a normalisation of political communication within partybuilt spaces.

Thus, it is hard to argue that party online presences have any role in enhancing broader democratic engagement. The BNP forum and Conservative's Blue Blog do however offer some tentative signs of progress and the election campaign did see a large amount of public (non-elite) use of the web to comment on the campaign and key events, particularly the televised debates, as well as on the outcome and how the parties should respond. The LibDem Voice independent forum in particular came alive as party leader Nick Clegg was given the role of 'kingmaker'. Equally contributions on news sites, via Twitter and Facebook forums as well as the Vote for Change and Vote for Democracy campaigns which crowdsourced support for voting reform suggest public involvement in debates being facilitated by the Internet and supporting to an extent arguments that it can play a role in enhancing the workings of democracy (Coleman \& Blumler 2010). However, such indications of broadening democracy remain outside of party online environments and their influence appears limited.

Despite the theoretical construct, and the experience of the Obama Presidential election campaign, the marketing imperative overrode any notion of participation. However, the divergent strategies demonstrate that the Conservatives, Liberal Democrats and BNP increased opportunities for participation, embedded themselves within the online network, but in an attempt to fulfil electoral goals. This suggests that, if resources are sufficient to monitor and orchestrate participation within the online campaigning elements, elections may well become more participatory in the future. However, conversely the imperatives of salesmanship may dominate strategy and Internet usage may equally serve as a marketing tool only with little role given to 
the big ideas of Web 2.0. What we do know is that the parties will increasingly use the Internet as a core internal marketing tool to enthuse, mobilise and direct the activities of internal audiences, alternative communication tools such as television are more likely to be targeted at floating voters.

\section{References}

Alani, F., (2010) Did social media change the 2010 General Election? Computer Weekly.com, online at: http://www.computerweekly.com/Articles/2010/05/14/241237/Did-social-mediachange-the-2010-General-Election.htm, accessed on 27/5/10.

Anderson, P. (2007) What is Web 2.0? Ideas, technologies and implications for education, JISC Technology and Standards Watch Report, February.

Anstead, N. and Chadwick, A. (2008) Parties, election campaigning, and the internet: toward a comparative institutional approach $\underline{I n}$ A. Chadwick \& P. Howard (Eds.) Handbook of Internet Politics, New York: Routledge.

Bernstein, J (2009) How the internet will impact the 2010 election, New Statesman, online at: http://www.newstatesman.com/blogs/the-staggers/2009/12/demos-prospect-rishi-sahaevgeny-mo, accessed on 27/5/10.

Birdsall, W. F. (2007) 'Web 2.0 as a Social Movement', Webology, 4 (2); http://www.webology.ir/2007/v4n2/a40.html accessed 30 September 2007.

Chadwick, A. (2007) Digital Network Repertoires and Organizational Hybridity, Political Communication, Vol. 24, No. 3, pp. 283-301.

Coleman, S., (2001) (ed) 2001: Cyber Space Odyssey - the Internet at the UK election, Hansard Society.

Dale, I (2010) General Election 2010: This was meant to be the internet election. So what happened? Online at: http://www.telegraph.co.uk/news/election-2010/7640143/GeneralElection-2010-This-was-meant-to-be-the-internet-election.-So-what-happened.html accessed on 27th May 2010.

Gibson, R, and Ward, S., (1998) UK Political Parties and the Internet: Politics as Usual in the New Media in Harvard International Journal of Press/Politics, 3 (3) pp14-38.

Gibson, R, and Ward, S., (2000) 'British Party Activity in Cyberspace’, In: R. Gibson and S. Ward, (eds) Reinvigorating Government? British Politics and the Internet, Aldershot: Ashgate: 155-207.

Gibson, R., Margolis, M., Resnick, D., and Ward, S. (2003) 'Election Campaigning on the WWW in the US and the UK: A Comparative Analysis', Party Politics, Vol. 9, No. 1, pp. 4776.

Jackson, N., (2006) Banking Online: the use of the Internet by political parties to build relationships with voters, In D. Lilleker, N. Jackson, R. Scullion, R. (2006) The Marketing of British Politics: political marketing at the 2005 General Election, Manchester: Manchester University Press.

Lilleker, D.G. and Jackson, N.A., (2011) Campaigning, Elections and the Internet: US, UK, Germany and France, Routledge.

Lilleker, D.G., Pack, M, and Jackson, N., (2010) 'Political Parties and Web 2.0: the Liberal Democrat Perspective’, Politics, 30 (2) 105-112. 
Lilleker, D. G. and Scullion, R. (2009) 'Political Advertising', in H. Powell, J., Hardy, S. Hawkins, I. MacCrury (eds) The Handbook of Advertising, London: Routledge: 187-197.

Norris, P., (2000) A Virtuous Circle: political communications in post-industrialised societies, Cambridge: Cambridge University Press.

O'Reilly, T. (2005) What is Web 2.0: Design Patterns and Business Models for the Next generation of Software'. Retrieved October 1, 2007 from www.oreillynet.com/pub/a/oreilly/tim/news/2005/09/30/what-is-web-20.html. Last accessed 6th May 2010.

Pack, M., (2010) After the election: Did the Internet make any substantial difference? Available Online at http://sluggerotoole.com/2010/05/18/after-the-election-did-the-internetmake-any-substantial-difference/. Last accessed $25^{\text {th }}$ May 2010.

Pullin, A., (2010) Internet will influence UK General Election: Can Facebook, Twitter magnetise the 18-24s, Tech Eye.net, online at: http://www.techeye.net/internet/internet-willinfluence-uk-general-election, accessed on 27/5/10.

Schweitzer, E. J. (2010). Global Patterns of Virtual Mudslinging? Comparing the Use of Attacks on German Party Websites in State, National, and European Parliamentary Elections. German Politics, Vol. 19, No. 2, pp. 200-221.

Schweitzer, E. J. (2011) 'Controlled Interactivity: Parties’ Online Campaigns in the 2009 German National Elections' in N. A. Jackson and D. G. Lilleker (Eds) Political Campaigning, Elections and the Internet, London: Routledge.

Stanyer, J., (2005) Political Parties, the Internet and the 2005 General Election: from Web Presence to E-Campaigning?, Journal of Marketing Management Vol. 21 (9), pp. 1049-1065.

Stromer-Galley, J. (2000) 'Online interaction and why candidates avoid it', Journal of Communication, 50 (4): 111-132.

Stromer-Galley, J. (2004). Interactivity-as-Product and Interactivity-as-Process. The Information Society, 20, pp. 391-394.

Worcester, R., (2010) Worcester's Weblog: after the Debate, online at: http://www.ipsosmori.com/newsevents/ca/ca.aspx?oItemId=474, accessed on 27/5/10. 